\title{
The Investigation on Reformation of Domestic Higher Education Administration System
}

\author{
Hongmei $\mathrm{Yu}^{1, \text { a }}$ \\ 1 Jilin Engineering Normal University, Changchun 130052, China. \\ ahongmei_yu@126.com
}

Keywords: higher education, management, reformation.

\begin{abstract}
With the building of socialist economy market system and development of educational service trade after entry WTO, domestic higher education administration system is encountering unprecedented challenge. In this paper, the system of higher education administration and service, which has an important theoretical and practical meaning on the management and it's joining global competition is established to improve the current status of education.
\end{abstract}

\section{Introduction}

Higher Education Management Plan refers to central or local governments, and colleges of education in accordance with national policies and laws, regulations, policies, to achieve the training objectives and aspects of higher education carried out, organizing, directing, coordinating, supervising and control a there is a continuous series of events purpose. It includes the macro-management of higher education and micro-management of higher education of two parts.

Traditionally, the macro-management of higher education refers to the state administrative department of education according to the law of development of higher education and the purpose of the national higher education; there are plans to coordinate the various relationships and resources of the entire higher education system, to ensure the country to cultivate high-level personnel to achieve the objective process. Solve the problem of the relationship between the government administrative departments of education and universities. This article explores the Management System of Higher Education from the macro aspects of.

Concept of higher education management system, there are several defining:

The first view is that: the management system of higher education is a "national agency set up in higher education administration, the relationship and division of responsibilities of the system, mainly clear state administration in higher education, which the government co-ordination and decision-making, how to divide responsibilities between them and the management of higher education institutions how it is an important part of the higher education system is a fundamental system of organization and management of its overall main principles are: higher education shall be clear State administration, the government is the main higher education administration; Second, the state administration of higher education should be borne by which level of government, what kind of management style, depends on a country's current political system, economic system and the specific conditions and cultural background; Third, higher education management activities of state or government must follow the law of higher education, to promote the development of higher education for the purpose of international law and rules-based management according to law.

The second view is that: the management system of higher education mainly refers to "all levels of government to manage and supervise the way the various forms of higher education, which also includes a school principal and investment relationship between education section, which is the essential attribute of the government's macro regulation, management and supervision. "Higher Education management system mainly reflects the state's basic requirements for higher education, it is the formation of higher education developed to a certain stage of the product, and understanding of the higher education management system mainly refers to the relationship between Government and Universities. 
Third view: the management system of higher education refers to the "fundamental organizational system of the state management of higher education, under normal circumstances, the main content is related to the provisions and adjustment of the central and local government and school." all the changes attributed to macro-management education system reformation and transformation of functions two ways.

The fourth point of view: the management system of higher education is "higher education activities in the relationship between the constituent elements of its organization and operation mode between."

Have focused on this view: some focus on the relationship between central and local governments, and some focus on the relationship between the government and schools, some both, but stressed that higher education should be managed by the state, the government is higher subject Education management, colleges and universities, other institutions of higher education is the object of management.

\section{Higher Education Management System}

Higher Education Management System is developed to a certain stage of the product is a reflection of a certain socio-political, economic and cultural.

With the gradual improvement and the rapid development of trade in education services market economic system, as a social intermediary organizations, higher education and services will become an important part of the management system reform of higher education; learn from the experience of other countries, social forces will also serve as an important management participation to the management of higher education in the past. Therefore, I will manage the national system of higher education is defined as general management of higher education organization system and related systems. The main form of organization including national management of higher education management at all levels of higher education institutions, the power structure of the State Higher Education Management and related higher education management system. It has the following five aspects of meaning:

First, the core management system of higher education is the National Administration Structure of Higher Education. Including the management of the distribution of power relations Higher central government and local governments, and higher education management powers of government authorities at all levels of higher education and other sectors to configure, manage all types of higher education institutions and colleges and universities at all levels of management between division of powers, and a variety of distribution of power relations internal management of higher education institutions.

Second, the various types of institutions of higher education management at all levels of the organization form the National Higher Education Management System. Management structure of the national higher education among the various types of power implicit in the management of higher education institutions at all levels.

Third, the management system of higher education is to make the management of higher education institutions functioning, play basic guarantee functions. Management activities and management functions of its management of higher education institutions play an important regulatory role.

Fourth, the formation of higher education management system is the result of the country's economic system, political system, cultural traditions and Investment in Higher Education, school system and other combined effects.

Fifth, the management system of higher education is a social cause in the institutional management, with dynamic characteristics. With the change in social conditions, the development of higher education system itself, the management system of higher education must be carried out with suitable changes.

Reform is regroup and form a new division of powers in the system of higher education system, organizational structure, mainly clear national higher education administration in government, colleges and universities (including schools in China to all forms of schools and Chinese Foreign 
relation to all forms of investment run by schools) and social (some scholars have called the market) between the core of which is the establishment of an optimized management mechanism. Its essence is to have the most reasonable division of the central and local government and the rights and obligations of the school and the community. Higher Education Management System mainly reflects the state's basic requirements for higher education; it is the formation of higher education developed to a certain stage of the product. This article only discusses macro-management system reform, that is, the relationship between the reform of government, universities and society issues. Therefore, I believe: the core and essence of Higher Education Management System is to change resource allocation model of higher education, the fundamental goal is to run a more efficient management system of higher education, the ultimate goal is to meet the broad masses of the people to accept the need for higher education. The core of our current phase of reform is to address the relationship between government, society, colleges and universities between the three, three-dimensional management system should be established central government, local government and society to intermediary service organizations of higher education as the basis, but also in accordance the development of political, economic and higher education, the idea of forming a tripartite mutual matching services, higher education management to achieve democratization and socialization.

\section{Current Situation of Higher Education Management System}

Our management system of higher education after 20 years of reform, many of power after the close of decentralization, now forms a central unified leadership of the central and provincial government two management to provincial governments based new system of higher education management, has made great achievements, but it is worthy of reflection on the lessons and experiences are not in the least. Objective, comprehensive, in-depth summary of the success of China's higher education should be an essential task.

Currently, the Higher Education Management System has made substantial progress in the implementation of the central and provincial, autonomous regions and municipalities directly under the two-level management to the provincial government dominated system. Central decentralization, expanding education and decision-making power to the central departments of the respective institutions the right to co-ordinate provincial governments, to place greater flexibility and autonomy in favor of the provincial government overall planning, local conditions, the development of local higher education, performing mainly in the following aspects:

Since reform and opening, with the reform of all aspects of higher education system, the central government has changed the pattern of taking higher education. Higher central government administration has shifted from the micro to the macro-control management authority Institutions of higher learning independent school expanded. With the joint school, build a condominium promote reform experiment, the provincial government to co-ordinate the gradual strengthening of the right to higher education; Central government on higher education management and centralized administrative intervention situation has been significantly changed. At the same time, means the central government institutions of higher learning are becoming increasingly diverse, steering legislation, funding, planning, information services, and policy guidance for the macro-management of the main means of directly from a single administration.

\section{Deepening the Reform of Higher Education Management Measures}

For in Higher Education Management System, combined with the actual China's economic, scientific and technological reform, deepen the reform of higher education, mainly to build a new system "trinity" of higher education macro-management services: central government macro-management, local government integrated management, community participation in the management of mutual cooperation and coordination with each other, to rely on the authority of intermediary organizations, service concept runs through the "trinity" of the macro-management services to the new system of higher education. By the management of the transition to the service, it 
is a major breakthrough in the understanding, but also consistent with the reform of government institutions in China.

In a sense, the current countries of the Higher Education Management System reflects some similarities and globalization of higher education, but I still have according to different social and cultural background to understand the formation of this trend. Because the management system of higher education has a special structure, reflects the deeply rooted in the times, society and local special idea, no two countries had adopted the same system in the form of higher education management. The author attempts to depart from such a position, summarized and analyzed from the perspective of multi-dimensional theoretical foundation of China's higher education management decentralization.

\section{Summary}

Higher Education Management System Reform of Higher Education is crucial in a ring which is related to the success of China's reform of higher education, but also to the rise and fall of higher education, theory and practice are strong. In researching this problem and want to accomplish something, we need to boldly explore and innovate. Subjectively speaking, this article Deng Xiaoping Theory and the important thought of "Three Represents" as guidance, to learn the valuable experience of Higher Education Management System, learn from the successful practices of some foreign countries, higher education reform, to build a new body of Higher Education Management make some useful exploration, we put forward some ideas and suggestions to relevant departments for reference. Due to the limited level, lack of information, it is difficult to do so. I would like to continue on this basis for the study of Higher Education Management System to make modest force. Society is advancing in the development of higher education; higher education management system reform is deepening. Research and exploration in this area is long way to go.

\section{References}

[1] Liling Han, Zhou Jianmin The Construction of government-led market-oriented higher education mode of Xi'an University of Architecture \& Technology, 2004 (4): 66

[2] Cai Keyong. Situation Century Chinese Higher Education Management System. Higher Education Research, 2014 (4) 7-11

[3] Zeng Kun students how Chinese higher education to meet the challenges of China's accession to WTO Soft Science, 2010 (11): 53

[4] Li Songlin, Xu Tianwei deepen the reform of higher education to adapt to the development of economic reform, Yunnan Normal University, 2009 (6): 72

[5] Zhang Yan basic ideas of Higher Education Management System of Qinghai University (Natural Science), 2003,21 (1): 66-68

[6] Higher Institute of Zhejiang University group comparative research of market economy countries Government and University Relations Hebei Normal University (Educational Science Edition), 2011 (4): 8

[7] Flower Nagatomo On the Innovation of Higher Education Administration System after Entry of Yangzhou University (Higher Education Study Edition), 2002, (1): 11-13

[8] In health reform and innovation 's Higher Education Management System of Dalian University of Technology (Social Science Edition), 2002 (2): 54 